Contrasting the conceptualisation of victims of trafficking for sexual exploitation: a case study of Brazilians in Spain and Portugal

\begin{abstract}
Despite the significant emphasis given to the trafficking of Brazilians to the sex industry of the Iberian Peninsula, the concepts of "victim of trafficking for sexual exploitation" used in these three countries vary. This article analyses the positions of Brazil, Spain and Portugal regarding the conceptualisation of "trafficking victim," focusing on their legislation and policies, as well as on relevant narratives which show how these policies are being applied. It showcases how the incompatible definitions being used compromise genuine anti-trafficking actions and may be an indicator that stopping trafficking may not be the primary concern of the policies developed by these governments.
\end{abstract}

\title{
Keywords
}

Brazil; Human trafficking; Portugal; Spain; Trafficking victim; Trafficking policy

This is a pre-print version of the published article. The final publication is available at Springer via http://dx.doi.org/10.1007/s10610-014-9265-3. 


\section{Contrasting the conceptualisation of victims of trafficking for sexual exploitation: a case study of Brazilians in Spain and Portugal}

\section{Introduction}

Brazil is considered one of the major source countries of women who are trafficked to the European Union (EU) for sexual exploitation. Among the receiving states, Portugal and Spain, countries with which it has strong historical and cultural ties, have held at times some of the largest declared numbers and percentages of its victims (Ministério da Justiça 2011).

This noteworthy human trafficking flow has been recognised as a problem by all three countries. It has resulted, from a policy standpoint, in a number of transatlantic meetings, declarations and agreements between the parties to ensure that traffickers are dealt with and victims protected. In practice, Brazil has taken part in a number of joint anti-trafficking operations with Spain (such as Castelo in 2004 and Ninfas in 2013), Portugal (Lusa in 2006 and Luxúria in 2009) and both countries at once (Castanhola in 2005), while Spain and Portugal have also collaborated in joint operations, particularly along their shared border (ICMPD 2011). When analysing these instances of cooperation it is clear that particular (if not exclusive) focus is given to combating trafficking for sexual exploitation

Considering the prominence given to the issue and the high level of multilateral cooperation involved, it would be reasonable to assume that all three countries would have compatible policies and definitions of human trafficking and that these would be based upon minimum international standards, particularly the United Nations (UN) Trafficking Protocol. ${ }^{1}$ We thus turn specifically to the Protocol's condemnation of the "exploitation of the prostitution of others or other forms of sexual exploitation" in the framework of human trafficking. The exact same language is used in the two foremost European instruments on the subject, the Council of Europe Trafficking Convention ${ }^{2}$ and Directive 2011/36/EU. ${ }^{3}$ However, in none of these documents is the term sexual exploitation defined, being left to the discretion of each state. There is thus no guarantee that these three countries use the same definition when considering what constitutes a victim of trafficking for sexual exploitation.

\footnotetext{
${ }^{1}$ Protocol to Prevent, Suppress and Punish Trafficking in Persons, Especially Women and Children, Supplementing the United Nations Convention Against Transnational Organized Crime (2000). Spain ratified the Protocol in 2002, while Brazil and Portugal did so in 2004.

${ }^{2}$ Council of Europe Convention on Action against Trafficking in Human Beings (2005). The Convention entered into force in 2008 for Portugal and 2009 for Spain.

${ }^{3}$ Directive 2011/36/EU of the European Parliament and of the Council of 5 April 2011 on preventing and combating trafficking in human beings and protecting its victims, and replacing Council Framework Decision 2002/629/JHA.
} 
This is highly problematic in a number of ways. If certain countries state that they have a common goal and strive to work towards it through, among other means, transnational judicial and police cooperation, having different interpretations of what constitutes the phenomenon is counterproductive. This may lead, for instance, to the development of inconsistent statistics and joint operations that have different objectives.

The main objective of this article is thus to assess whether the concepts of (transnational) "victim of trafficking" for sexual exploitation have been constructed in compatible ways by Brazil, Spain and Portugal. In particular, we will determine whether the concept is being erroneously used by one or more countries to refer to all migrant sex workers and what consequences this can have.

This assessment will be conducted in two separate stages for each country. First, we will consider how the concept of victim is defined in the anti-trafficking legislation and policies and how this concept has evolved over time. Secondly, we will determine whether the established definition is used in practice by police forces, the judiciary and other relevant organs. We will also assess whether those who fulfil the definition of a (potential) victim of trafficking benefit from the provisions laid out in the relevant legislation and policies or whether they are in practice treated as undocumented migrants.

Unlike the evaluation of the construction of the official concepts of "victim of human trafficking," the appraisal of how legislation and policies are being and have been applied will not be based solely on official government discourses. Rather, the assessment of the actual identification and treatment of these victims will be constructed through accounts of relevant non-governmental and transnational organizations, academics, police and migration officers, members of the judiciary and, of course, migrant sex workers and victims of trafficking for sexual exploitation themselves. These accounts have been obtained primarily through institutional publications (sponsored by national and regional governments, international organizations and civil society representatives), ethnographic and other relevant academic studies (such as theses), and newspaper reports addressing the issues of human trafficking, sex work and migration in all three countries.

\section{Brazil}

\section{Local Legislation and Policies}

Human trafficking has been typified in Article 231 of the Brazilian Penal Code (BPC) since 1940. At the time trafficking, a crime against sexual liberty, consisted solely of promoting or facilitating the movement of women (into or out of the country) for the purpose of prostitution and did not take into account the consent of the alleged victims or if any exploitation was planned or took place. 
In 2005 major changes were made to this definition. Two of them were the replacement of the term "women" by "someone" and the introduction of Article 231-A, typifying internal trafficking. A second amendment took place in 2009, when (among other things) the term "other forms of sexual exploitation" was added to the law. Note that the Brazilian legislation, unlike the UN Trafficking Protocol, does not condemn "the exploitation of the prostitution of others," but prostitution in itself, which in this context is equated to a form of sexual exploitation.

As it current stands, ${ }^{4}$ Article 231 of the BPC reads,

\section{International trafficking in persons for the purpose of sexual exploitation}

Art. 231. Promote or facilitate the entry into national territory of someone who will engage in prostitution or other form of sexual exploitation, or the exit of someone who will engage in it abroad.

Sentence - incarceration, from three to eight years.

\$1 Incurs the same sentence the person who handles, recruits or buys the trafficked person, as well as those who, aware of his/her condition, transport, transfer or harbour him/her.

$\$ 2$ The sentence is increased by half if:

$I$ - The victim is younger than eighteen years of age;

II - The victim, due to infirmity or mental deficiency, does not have the necessary discernment to practice the act;

III - If the agent is a parent, grandparent, stepparent, sibling, stepchild, spouse, companion, tutor or caretaker, preceptor or employer of the victim, or if he/she assumed, by law or other form, obligation of care, protection or vigilance;

$I V$ - There is the use of violence, grave threat or fraud.

Despite the fact that the UN Protocol was ratified by Brazil in 2004, the BPC still only contemplates trafficking for sexual exploitation, which, when it concerns adults, is treated as an offence whose primary concern is public morality. Moreover, it depends solely on two single variables: conduct (recruitment) and purpose (prostitution, which is read as exploitation), ignoring the necessity of means (coercion, abduction, etc. $)^{5}$ for trafficking to take place, the consent of the victim (even if non-vitiated), and the possibility of non-exploitative yet non-autonomous migrant sex work.

The absence of exploitation as a key component of the definition can lead to a rather broad perception of what constitutes "facilitate" in this context. In the assessment of

\footnotetext{
${ }^{4}$ Law Project 479/2012 - which was approved by the Brazilian Senate in April of 2014 and is currently under review by the Chamber of Deputies - intends to change this definition. If ratified in its current form it will, among other things, shift the classification of trafficking to a crime against human dignity, introduce other forms besides sexual exploitation (such as slave labour and organ removal), make the means described in the UN Protocol a pre-requisite for the crime and eliminate the use of the word "prostitution," substituting it for sexual exploitation.

${ }^{5}$ The use of violence, grave threat or fraud and the (implied) use of a position of vulnerability or power are not mentioned as pre-requisites, but as aggravations to the crime.
} 
Public Prosecutor Ella Wiecko de Castilho (2006: 2), this "aid" is not restricted to lending money (at a profit or not) or helping the person obtain travel documents (legally or not), but can also include things like buying clothes or any other necessary things for the journey. Thus, anyone who knowingly participates in the migration process of a (future) sex worker can be charged as a trafficker, even if no exploitation takes place. This ample interpretation is problematic because a large number of people, working in a variety of sectors, are aided in their migration process, not always in a strictly monetary way or even at a cost (Piscitelli 2006: 5).

Thus, according to the BPC practically all migrant sex workers can be classified as victims of human trafficking for sexual exploitation and the only migrant prostitution which can legitimately take place is that which is completely autonomous. This offers an interesting parallel to the legal standing of prostitution in Brazil, which is in itself not criminalised. Rather, the Brazilian state has long since adopted an abolitionist position in which adult prostitution is tolerated (although not regularised), but in terms which imply that prostitution is in itself sexually exploitative. ${ }^{6}$ As it happens in the context of trafficking, only prostitution which is completely autonomous is tolerated.

Besides trafficking for prostitution, Article 231 also condemns that which involves "other forms of sexual exploitation." This term, however, is not defined in the BPC, nor is a definition present in either the National Trafficking Policy or the National Trafficking Plans (Secretaria Nacional de Justiça 2008, 2013). However, in the "Reference guide to the network facing human trafficking in Brazil" (Teresi and Healy 2012), sponsored by the Ministry of Justice, there is a definition of sexual exploitation used as reference, which was in fact taken from a publication of the Brazilian office of the International Labour Organization (ILO):

Commercial sexual exploitation is a crime and occurs when men and women are forced to enter prostitution. It also occurs when they enter prostitution of their own free will, but are hindered from leaving it. (p. 15)

In the case of adults, prostitution is considered commercial sexual exploitation or forced prostitution when forced labour characteristics show up: restriction of freedom, debt bondage, retention of documents, threats, etc. ... In situations of sexual exploitation, the victims, be they adults of either sex, children or adolescents, are exposed to different kinds of violence, such as psychological pressure, physical ill-treatment, beatings, humiliations, slander, libel, sexual harassment, rape and murder. (p.14) (Miranda et al. 2009; emphasis added).

\footnotetext{
6 The abolitionist approach to sex work - which is taken not only by Brazil, but also by Spain and Portugal - tolerates the activity, but does not consider it a job like any other. Sex workers are seen as victims, not workers, and thus profiting from the prostitution of others or inducing others into prostitution is prohibited. In all three countries brothels are, in theory, prohibited, but places which act as de facto brothels (such as highway clubs) are tolerated to an extent.
} 
Here there is a very clear emphasis on the fact that not all kinds of prostitution consist in sexual exploitation and that some kind of mistreatment (physical, psychological) must also take place. This position, while still in line with the UN Trafficking Protocol, contradicts the BPC definition.

This duality when it comes to the definition of sexual exploitation in the context of human trafficking, which is understandably problematic, is reinforced by different state agents. Both positions were, for instance, presented in 2010 by official government representatives during the "I Seminar regarding Brazilian migration and gender issues." The Ministry of Justice (responsible for backing most of the anti-trafficking policies that have been implemented, as well as funding trafficking research) put forth the broader UN definition of trafficking which is used in the National Trafficking Plans and Polices; the Federal Police highlighted the BPC definition and in broad terms condemned the prostitution of Brazilians abroad regardless of the condition and wishes of the sex workers (Piscitelli 2011: 16-17).

\section{Law and policies into practice}

The Federal Police is in practice responsible for enforcing the Brazilian migration policy and for investigating potential cases of transnational (and at times internal) human trafficking. Its decision on whether to abandon or pursue an investigation makes all the difference when it comes to establishing a legal case about a potential trafficking situation.

There is no doubt that the Federal Police has been responsible, often by working alongside law enforcement agencies from other countries, for apprehending traffickers and aiding victims as understood in the terms of the UN Protocol. Yet not all cases persecuted seem to be targeting exploitative situations. Official statements from its representatives seem to indicate that the Federal Police bases its actions solely on the trafficking definition enshrined in the BPC and this is reflected in the cases it pursues. This is very clear, for instance, in cases that are "discovered" during the so-called "preventive actions in the inspection of airports" (Blanchette 2012: 18).

The following situation was presented during the Senate's trafficking commission hearings (Senado Federal 2012). In March of 2012 the Federal Police arrested in the Guarulhos airport a taxi driver who was flying to Namibia in the company of seven women, having been alerted to "suspicious circumstances" by the police in the Rio de Janeiro airport, where they had initially boarded. The police found out that the women were supposed to spend a weekend with Angolan businessmen with whom most had had previous contact. Evidence suggested they would be exchanging sexual services for money, even though they officially worked as receptionists and escorts. Each would receive U\$ 3000, although half the money would go to the handler, who had also paid for the plane tickets. The women refused to abandon their journey when prompted by the police, had return tickets, seemed to be perfectly aware of what the trip entailed and 
would be remunerated accordingly. There was no evidence that force or deceit had been used, that any exploitation would take place or that they would be forced to remain in Namibia. Despite all this the Police refused to let the group board the plane to Africa and charged the taxi driver not only with lenocinio (aiding and profiting from the prostitution of others), but also with trafficking. It is clear that the standards of article 231 (which basically translate to aiding the international movement of those who will participate in sex work abroad) were used, as neither the means nor the exploitation outlined by the UN Protocol as necessary for the existence of trafficking seemed to take place.

This clearly highlights the previously mentioned contradictory official position of state authorities. While the National Justice Secretary affirms that people are free to go abroad, even if to perform sex work (Abrantes 2013), the Federal Police has a policy of stopping those Brazilians who are deemed to be "suspicious" at border crossing points (personal communication, June 24, 2014). This translates, in practice, to profiling people on their susceptibility to trafficking based solely on their physical appearance and distorting article 240 of the Penal Procedural Code so that people may be temporarily detained as evidence of their own potential victimisation.

The declaration made during the First National Anti-Trafficking Seminar in 2007 by retired prostitute and sex workers' rights activist Gabriela Leite seems then prophetic: "A lot has been said here about fighting human trafficking, but on a day to day basis what will happen is that the whores will be arrested and labelled as 'trafficking victims" (Blanchette and da Silva 2010: 355). As to why this happens, the head of a Brazilian anti-trafficking non-governmental organisation (NGO) claimed in 2009 that the country "is concerned about answering the UN's demands to contain the migratory influx of Brazilian women to Europe and not with creating measures that can contain the number of trafficked women and offer a more humane reception to the victims" (Piscitelli 2006: 78).

These declarations become particularly relevant when we consider that the repressive measures undertaken under the "anti-trafficking" umbrella have not been restricted to targeting women and trans ${ }^{7}$ who attempt to cross borders, but have also surfaced in the return of vice operations supposedly targeting trafficking in cities such as Rio de Janeiro, which have led to the arrest of virtually no traffickers, but have brought significant negative impacts to the lives of sex workers (Amar 2009).

Sex workers are also negatively impacted by the fact that they are marginalised in the development of the government's anti-trafficking policies. Prior to 2007 sex workers' rights organisations were completely excluded from the debate (Blanchette and da Silva

\footnotetext{
${ }^{7}$ The emic term "trans" is being used here to refer to "travestis" (as per the terminology used in Brazil), as well as transsexual and transgender persons. Because there appears to be no data or mention of trans male individuals in the context of trafficking and the sex industry in Brazil, "trans" shall refer to individuals who were assigned male at birth and were, to some degree, dissatisfied with this label.
} 
2010: 340). Although this has slowly started to change, it is often the case that when sex workers are included they are seen as mere victims and consequently have their voices suppressed, leading some of them to become very reluctant to work with the government (Piscitelli and Sprandel 2011).

This infantilisation and marginalisation of sex workers is particularly problematic because this means that the likelihood of future anti-trafficking policies becoming de facto anti-prostitution mechanisms, as it has happened previously, only increases. Moreover, the very valuable first-hand knowledge prostitutes possess about the reality and problems of those who migrate to work in the sex industry abroad is completely belittled and ignored.

Another serious issue with Brazil's anti-trafficking policy is the fact that the Federal Police does not offer official statistics regarding the number of trafficking victims it has identified, although it does offer data regarding the persons charged with committing a trafficking offense and the number of police investigations that fall under article 231 (Ministério da Justiça et al. 2013). There are likewise no reliable national statistics from the judiciary system regarding the number of alleged victims who have been "confirmed" during criminal proceedings, nor there seems to be a way to access all of the cases tried under article 231 (Senado Federal 2012). ${ }^{8}$

Data regarding the number of Brazilian victims of international trafficking for sexual exploitation, however, has become available for the 2005-2012 period. The numbers adopted as official by the government have been acquired through the Ministry of Foreign Relations, which utilizes the UN Protocol definition (personal communication, August 5, 2013). The Ministry, however, only counts as trafficking victims those who contact the consular authorities for help to return to Brazil or to obtain temporary shelter, accounting for a mere fraction of the victims identified abroad.

The Foreign Ministry is charged with offering adequate training to the staff of its consulates so that trafficking victims can be identified, aided and even taken to Brazil at the government's expense if they wish to return and cannot afford to do so. In practice, however, the consulates do not always prove to be a source of help. There is a widespread perception among certain Brazilian migrants that the consulates are not interested in aiding people like them: poor, trans, sex workers and/or who are in an irregular situation. While help has been denied more than once at certain consulates to people who fit one or more of these categories, so far there has not been sufficient

\footnotetext{
${ }^{8}$ While it seems unlikely that a systematic appraisal can be made of whether the victims and traffickers identified by the judicial system are classified according to the standards of the UN Trafficking Protocol or Article 231 of the Penal code, some small scale research has been undertaken by NGO Projeto Trama (Procuradoria da República 2013) (28 cases) and Ferreira (2009) (19 cases). The results show that the UN Protocol is rarely, if ever, mentioned in trafficking sentences and that people are often condemned as traffickers simply for aiding the migration of sex workers, even when there is no evidence of fraud, coercion, abuse, exploitation or financial gain. The moral condemnation towards prostitution is very clear in multiple judicial sentences.
} 
information to affirm that this reflects a systemic problem rather than isolated incidents which may be limited to a few consulates (Blanchette and da Silva 2011: 94). ${ }^{9}$ Even if the consulates could prove to be helpful, there have also been reported cases in Europe where, despite it being illegal, local authorities have not allowed Brazilian migrants who have been detained to contact the consular authorities (Secretaria Nacional de Justiça and ILO 2007: 112).

Yet the problems are not solved when victims manage to return to Brazil. Although there are support structures for victims of trafficking coming from abroad (most notably the humanised assistance offices for migrants ${ }^{10}$ and the anti-trafficking nuclei which are present in several states), they are not well known and, unless there is a proactive involvement in the reception of trafficking victims at the borders, not likely to be sought (Procuradoria da República 2013). ${ }^{11}$

Victims that need greater support are often let down. There are no specialised shelters in Brazil to harbour trafficking victims, who are put into those existing few which house either the homeless or drug addicts and do not have adequate facilities to receive families or trans victims (Procuradoria da República 2013). Despite the fact that victims of labour exploitation (who are often male) have been detected with increasing frequency, much of the focus is still placed upon female (and to a lesser extent, trans) victims of trafficking for sexual exploitation (Secretaria Nacional de Justiça 2006; Secretaria Nacional de Justiça and ILO 2007; Ministério da Justiça et al. 2013). This means that male victims are often made invisible and frequently simply considered as (undocumented) migrants who had "bad" experiences (Agustín 2007).

Those that need further protection are in even worse straights. Brazil has had since 1999 a somewhat efficient general witness protection program, but PROVITA has proven to be inadequate to deal with trafficking victims. Although the official guidelines of the program do not make it a pre-requisite, in practice only those victims who have gone on record against their traffickers are offered protection. Even then, there is a considerable delay between the request to enter the program and the provision of protection. PROVITA does not have the infrastructure or the budget to guarantee the safety of the victim's whole family, which is often threatened by traffickers, particularly if they are in another state. Moreover, the structure of the program is such that victims of

\footnotetext{
${ }^{9}$ Blanchette and da Silva's observations are based on anecdotal evidence from a limited number of sex workers who have returned to Brazil. Although Professor José Carlos Sebe Bom Meihy is undertaking research on the subject, having amassed accounts from more than seventy trans sex workers, his observations are limited to Brazilian diplomatic representations in France (Procuradoria da República 2013).

${ }^{10}$ These outposts are present along selected migration hubs (such as international airports) and are supposed to, among other things, provide information and support to previously identified trafficking victims and identify through interviews previously unknown victims that have been deported or denied entry abroad.

${ }^{11}$ This reception problem may be exacerbated by the fact that most channels trafficking victims go through are now under the authority of government officials (such as the police), rather than through the much less intimidating NGOs.
} 
trafficking are often re-victimised, being submitted to a high level of movement constraint and even having further rights infringed upon (Procuradoria da República 2013).

Lastly, it is not easy for victims to re-establish their lives once they are in the country. The "Return to Brazil" guidebook developed by the Foreign Ministry (Ministério das Relações Exteriores et al 2010) gives information about how to contact government programs that encourage returning migrants to work with handcrafts, construction and agriculture - the same kind of labour intensive, low-income jobs most of them had before leaving the country in search of a better life.

\section{Spain}

\section{Local Legislation and Policies}

The history of the anti-trafficking legislation in Spain is relatively recent. Its provisions can be found primarily in two sources of law: the penal code and Ley Orgánica $(L O)$ 4/2000 (the so-called Ley de Extrangería, which regulates "the rights and liberties of foreigners in Spain and their social integration"), both of which have been modified a number of times throughout the years.

LO 4/2000, in its article 55 (later changed to article 59 by $L O 8 / 2000$ ), ${ }^{12}$ focused on collaboration against organised networks. It granted undocumented migrants who were smuggled or trafficked (the term "tráfico"13 was here used interchangeably) by those who abused their "necessity" the possibility of a pardon for their administrative infraction and a chance to avoid deportation. To obtain this reprieve they had to report their traffickers/smugglers or collaborate with the competent authorities, either presenting essential information or testifying against members of the criminal network. It is thus very clear that the legislation was little concerned with the welfare of the undocumented migrants, who could only benefit from its (limited) provisions if they proved to be an asset during criminal proceedings.

The Ley de Extrangería also introduced article 318 bis to the Spanish penal code. This article penalised those who promoted or facilitated "tráfico ilegal" to or through Spain. No differentiation was made between trafficking and smuggling, leaving trafficking victims without a specific recourse. ${ }^{14}$ Exploitation, in fact, was not mentioned at all,

\footnotetext{
${ }^{12}$ Article 59 was later further modified by $L O 14 / 2003$ and $L O 2 / 2009$, but its basic premise remained.

13 Although by now mostly overcome, it is important to note that for many years there was a certain amount of confusion over the appropriate term used to refer to human trafficking in Spain. Trata (now used to designate trafficking) and tráfico (now used to designate smuggling) were used interchangeably, not only in news reports, but also in official documents.

${ }^{14}$ The only exception was trafficking for sexual exploitation, which was added as a subset of article 188 (which covered rufianismo, the exploitation of the prostitution of others) by $L O 11 / 1999$.
} 
although submitting people to circumstances which endangered their life, health or integrity was considered an aggravating circumstance.

Article 318 bis was modified by $L O$ 11/2003 (and later on by $L O$ 13/2007). There continued to be no differentiation between the concepts of smuggling and trafficking, which by then were detailed in the UN Trafficking and Smuggling Protocols that had already been ratified by Spain. ${ }^{15} \mathrm{~A}$ significant change was brought, however, with the addition of a paragraph detailing that if the purpose of the "tráfico" was sexual exploitation, a higher sentence could be warranted. This presented a number of problems. First, the only form of exploitation recognised was sexual, as if no other forms (such as forced labour) existed. Secondly, the wording of section one of the article only considered the existence of "tráfico" in cases of irregular entry into the country, which do not account for all cases of human trafficking, as victims may enter the country legally and still be subjected to exploitation. Finally, although the article recognised a particular subset of victims (undocumented migrants trafficked for sexual exploitation), this only led to potentially higher sentences to the traffickers, with no provisions being made for the welfare of the victims.

In its 2005 trafficking report, the Guardia Civil (Civil Guard) outlined for the first time which articles of the Spanish Penal code covered the varieties of human trafficking as established by the UN Protocol. ${ }^{16}$ These offences were then clearly differentiated from migrant smuggling, although the two terms were still often used interchangeably by official sources at the time. In practical terms, however, the Spanish government only addressed trafficking for sexual exploitation and even then in a problematic way. Sexual exploitation was said to cover, per the UN Protocol, the exploitation of the prostitution of others and other forms of sexual exploitation. ${ }^{17}$ This exploitation of the prostitution of others was further divided into two categories: coercion/profit from prostitution and illegal "tráfico"/clandestine migration with sexual purposes (established in article 318 bis), which did not need to involve exploitation at all.

While Spain tightened its borders against irregular migration, the discussion about the situation of prostitution in the country took a prominent place in the public sphere. In 2007 the Spanish legislature held an extensive debate on the subject. Although it did not bring about any legal changes (the abolitionist position continued to prevail), the resulting report did offer some interesting insights into the perception of sex work in the country, such as the rampant (although not unchallenged) assertion that prostitution and

\footnotetext{
15 The means - an essential part of the UN trafficking definition - are present, but they are only seen as aggravations to the smuggling, rather than as indicators of a separate crime.

16 Forced labour or services, slavery and practices similar to slavery and servitude were put under the heading of labour exploitation, followed by a separate category for organ removal. In a situation similar to Brazil's, these crimes were only punished by themselves, as there were no trafficking provisions which encompassed them, despite the fact that Spain had ratified the UN Trafficking Protocol in 2002. Child trafficking, on the other hand, was a category on itself.

17 Interestingly, all "other forms of sexual exploitation" cited by the Guardia Civil involve minors (specifically their corruption and use in pornography).
} 
human trafficking are strictly linked. Without citing sources, it claimed that "the majority of women in a situation of prostitution are or have been victims of human trafficking" (Cortes Generales 2007: 23). Moreover, the report cited more than once as one of its main inspirations the 1949 "Convention for the Suppression of the Traffic in Persons and of the Exploitation of the Prostitution of Others," 18 which classifies all prostitution, regardless of the consent of the person performing it, as a form of sexual exploitation which is incompatible with human dignity. To an even greater extent than in Brazil, the concepts of "morality" and "decency" (which are held up as timeless and immutable) are often used in Spain as a justification to oppose prostitution (Surt 2007: 21).

Following the 2007 nationwide debate about prostitution and its conclusions, the Spanish government launched in 2008 the I Plan Integral de Lucha contra la Trata de Seres Humanos con Fines de Explotación Sexual (2009-2011). In it "sexual exploitation" in the context of trafficking was defined as encompassing prostitution as a whole, sex tourism, the buying of mail order brides and servile marriages. Rather than focus on exploitation, the plan seemed to condemn any sort of monetary (or equivalent) exchange for sexual services, regardless of its context. Proxenetas (those who profit from prostitution) and traffickers were treated interchangeably and it was taken as a universal truth that trafficking "of women, boys and girls" only exists because prostitution exists (Ministerio de Igualdad 2008).

In 2009, after the launch of the Plan, the Ley de Extrangería underwent a significant change. A new article, 59 bis, specifically covering "victims of human trafficking", was added by $L O 2 / 2009$ (and later modified by $L O 4 / 2010$ ), finally differentiating between smuggled migrants and trafficking victims. It established that a thirty day reflection period, which could be renewed once, might be offered for identified victims of trafficking, during which deportation procedures would be halted. ${ }^{19}$ In "exceptional" cases residence permits could be granted due to victims' personal circumstances or their role in aiding the investigation and/or criminal procedures against their traffickers.

Article 59 bis also established that victims should be identified according to the provisions set in Article 10.2 of the Council of Europe Trafficking Convention, which reads in part: "Each Party shall adopt such legislative or other measures as may be

\footnotetext{
${ }^{18}$ Although both Brazil and Portugal are also signatories of the 1949 Convention and have not denounced it, neither country cites it as a strong basis of its trafficking policies, referring rather to the UN Trafficking Protocol.

${ }^{19}$ A reflection period does not need to be offered in all cases. Although the Protocolo Marco de Protección de las Víctimas de Trata de Seres Humanos (Gobierno de España 2011) does not clarify in which circumstances one may be denied, it does say that the reasoning may not be depended on the fact that the victims may have chosen not to give statements or collaborate with the authorities. In 2011, 4338 trafficking cases were confirmed (from 28970 potential ones), but only 763 reflection periods were offered, 98 of which were accepted. (Secretaría General de Políticas de Igualdad and Delegación del Gobierno para la Violencia de Género 2012: 37, 40). 51 residence permits were granted by Spanish authorities in that year and all but one were granted due to cooperation with investigative procedures (GRETA 2013: 51).
} 
necessary to identify victims as appropriate in collaboration with other Parties and relevant support organisations." The Spanish Protocol of Identification (Gobierno de España 2011), however, was only developed in late 2011. Unlike the Trafficking Plan, it covers both labour and sexual exploitation.

It was not until $L O 5 / 2010$ that a true "trafficking" article, as per the UN Trafficking Protocol understanding, was added to the Spanish legislation. Acknowledging that addressing both trafficking and smuggling in article 188 bis was inappropriate, a new subcategory of the penal code (Title VII bis, focused exclusively "On Human Trafficking") was created. Its sole article, 177 bis, reads, in part,

1. A person will be punished with a sentence of five to eight years imprisonment as a human trafficking defendant who, be it in Spanish territory, be it from Spain, in transit or bound for it, employing violence, intimidation or fraud, or abusing a situation of power or necessity or vulnerability of the victim, national or foreign, captures, transports, transfers, harbours, receives or takes in the victim with one of the following purposes:

- The imposition of forced labour or services, slavery or practices similar to slavery, servitude or begging.

- Sexual exploitation, including pornography.

- The removal of organs. ...

3. The consent of a victim of trafficking in human beings shall be irrelevant if any of the means set forth in paragraph one of this article took place.

The above definition of human trafficking finally goes beyond the focus on sexual exploitation $^{20}$ and takes into account the consent of the person involved when the situation warrants it. The use of the term "necessity" and the inclusion of the victim's "situation" as a possible cause of particular vulnerability, however, leave open the possibility that persons of diminished socio-economic means will be branded as unable to consent. It is a recurrent abolitionist interpretation that the lack of financial means (and, although less mentioned, of extensive education) leaves people with "no other alternative" than to turn to prostitution. This rhetoric is often used when dealing with migrant sex workers from developing countries, regardless of their specific situation. ${ }^{21}$

\section{Law and policies into practice}

The genesis of the Spanish trafficking victim identification system may be traced back to the Directiva de Servicio 3/2000 of the Spanish Civil Guard. The Directive established that, in order to curb the exploitation of minors and detect trafficking cases,

\footnotetext{
${ }^{20}$ It is interesting to note that the term "prostitution" is absent here, while pornography is explicitly stated as able to be a form of sexual exploitation. However, per the Spanish Trafficking Plan still in use, sexual exploitation does include prostitution in all its forms.

${ }^{21}$ See for instance the work of Kathleen Barry, the founder of prominent abolitionist group CATW (Coalition Against Trafficking in Women).
} 
periodic inspections ${ }^{22}$ should take place in known prostitution establishments located in the jurisdiction of the Guard, which consist mostly of "highway clubs." The Guardia Civil, claims that these establishments harbour around $80 \%$ of the total of sex workers in Spain (with the other $20 \%$ working in urban centres, in locations that vary from the streets to luxury apartments), but this assertion has been hotly contested (Agustín 2007: 144).

During these "inspections" (which are perhaps more akin to raids) a (usually female) specialist of the "Women Minors Team" (EMUME) is supposed to approach the sex workers separately, question them about their situation and inform them of their rights (particularly the benefits they can gain if they report their exploiters and the security that can be given to them if they do so). ${ }^{23}$ These interviews apparently last from three to four minutes (Andreu 2013).

The Civil Guard releases an annual report with data from these inspections in which the number of "victims" of trafficking for sexual exploitation can be found. Their definition of victim, however, is quite broad:

although technically this denomination [of victim] should only be applied to a person that reports their situation, for the effects of this report [the Guardia Civil] will also consider "potential victims" the people (mostly women) who engage in prostitution in these establishments, because [we] understand that they do so without any administrative support, due to finding themselves in a situation of necessity (although not all of them) and because, making an accusation or not, there is always the lingering doubt of whether they engage in this activity under the greater or smaller control of people and organisations dedicated to illegal activities (Guardia Civil 2005: 12).

Rather than justify the perception that all foreign sex workers are (potential) victims by pointing out that nearly all of them share some of their earnings with third parties (such as club and apartment owners), which fits the Spanish definition of rufianismo, the angle most commonly exploited is their alleged situation of necessity and lack of support, which would invalidate their consent to sex work, as they are perceived as having no other choice. Thus, a link to prostitution in itself, rather than to rufianismo, becomes the only requirement to label a foreign woman as a victim.

\footnotetext{
${ }^{22}$ Directiva de Servicio 40/2009 established that these "preventive inspections" were to take place at least once a year.

${ }^{23}$ Although the Guardia Civil is often the most cited police force when it comes to investigating trafficking in Spain, the Cuerpo Nacional de Policía is also very much involved, having brigades exclusively dedicated to combating the phenomenon. It seems however, that the Cuerpo takes a stricter position than the Guardia and considers as potential victims only those that present actual signs of exploitation rather than all migrant sex workers (Teresi 2007: 93). Data from the $C N P$, however, is not easily made available to the public and thus is much less often used in the trafficking debate.
} 
Note that these "victims" need not show any of the usual signs of a potential trafficking situation (violence, control, the presence of a debt or retention of documents): working as a prostitute is enough to acquire the label. Nor is there any indication whatsoever that these cases undergo a scrutiny longer than a brief conversation between the trained police officer and the alleged victim to determine whether trafficking is indeed taking place. There is also no way to ensure that the same woman will not be counted twice. Considering the widespread plaza system in Spain, in which women usually spend twenty-one days in a particular establishment before moving to another, ${ }^{24}$ the possibility of sex workers being counted multiple times, in different cities and even communities, is not a small one.

The disparity between the number of "(potential) victims" and alleged victims which have reported being exploited (but whose status has not been confirmed) is immense. In 2002 despite there being 23,020 "victims" (read, sex workers) counted by the Civil Guard, only 236 presented themselves as victims of trafficking, which amounts to almost $1.03 \%$ (Guardia Civil 2002). Although there is always the possibility that a number of women did not make a formal complaint due to fear or other motives, the disparity is still very large and has continued over the years. In 2012, of the 12,305 persons identified as "at risk" by Spanish security forces, only 125 were legally recognised as victims of trafficking, totalling less than $1.02 \%$ of at risk cases (Secretaría de Estado de Servicos Sociales y Igualdad and Delegación del Gobierno para la Violencia de Género 2012: 37).

This focus on looking for victims of trafficking by raiding places that are considered to be brothels carries a lot of problems. It ignores the fact that situations of extreme exploitation and violence also take place in other forms of trafficking, particularly labour exploitation. Furthermore, sexual exploitation in the context of trafficking is not confined to the sex sector, but also takes place in other contexts, particularly domestic service. Finally, by focusing solely on migrants whose situation in the country is irregular, it ignores the fact that regular migrants may also be subjected to trafficking and exploitation. ${ }^{25}$

Besides these issues, one must also not discount the extremely negative effects these "inspections" bring to sex workers, such as the loss of time and money (not only during the operation, but on subsequent days when clients are still wary). Raids such as these, which often lead to a massive number of deportations and may even result in violence,

\footnotetext{
${ }^{24}$ The plaza system's three weeks length is supposedly tied to the length of women's menstrual cycles, allowing, in theory, sex workers to complete a non-stop work cycle and take time off for their period. Its widespread use in Spain, however, may be more linked to the fact that sex workers usually earn more when they are new to a particular place and that constant movement seems to be a strategy to bypass police checks. A similar placement system also exists in Portugal, although its length is usually fifteen days (Riopedre 2010: 658).

${ }^{25}$ Data from 2011, for instance, shows that only $40 \%$ of persons identified as "at risk" of being victims of trafficking (i.e. sex workers) were irregular migrants (Secretaría General de Políticas de Igualdad and Delegación del Gobierno para la Violencia de Género 2012: 37).
} 
also position the police as actively working against sex workers, making it more unlikely for them to confide in officers in the event that something is wrong. ${ }^{26}$ The fear of the police leads many prostitutes to work in isolation, undermining their security even further (Global Network of Sex Work Projects: 3-4).

In the assessment of a significant percentage of Brazilian sex workers in Spain, these anti-trafficking (and in practice anti-migration) operations are to them a greater concern than trafficking itself (Piscitelli 2012: 300). Numerous migrant sex workers have made allegations of ill-treatment, which includes physical and verbal abuse, against the migration and police officers who are part of the brigades responsible for identifying trafficking victims (Piscitelli 2006: 8).

These identification raids are thus problematic by their nature, a fact which is only made worse when we consider that the actual identification and support of trafficking victims which is supposed to be their goal seems to be relegated to a secondary concern, if that. The "investigations" seem to be more of a socially acceptable way to detect and expel undesirable irregular migrants and curb sex work or at least make it less visible. In the words of a Brazilian woman exploited in Spain,

From what I have seen, from what I see, the police does not know if the girl is paying [a] debt, if she's not paying [a] debt, or will see what is happening, or what is not happening. The police goes to see if you are illegally in the country and that's it. (Federación de Mujeres Progresistas 2008: 350).

The Identification Protocol, which has existed only since late 2011, has created parameters for the assessment interviews, although whether or not they are being used and whether they can ensure that a victim is identified in less than five minutes is a matter of debate. Prostitution in itself is not identified in the Protocolo Marco as an indicator of trafficking (contradicting somewhat the vision of the Guardia Civil). Rather, certain working conditions (such as excessive retention of money, working while sick or menstruating and the existence of abusive and/or irrational sanctions) are highlighted as being problematic. ${ }^{27}$ Other somewhat arbitrary trafficking indicators in the Protocol include coming from a (perceived) known country of origin, having a low socio-economic status and one or more children (Gobierno de España 2011).

The Protocol brings to mind Article 59 bis of the Ley de Extrangería, which establishes that in Spain, as per the terms of article 10.2 of the Council of Europe Trafficking Convention,

\footnotetext{
${ }^{26}$ This is made more problematic by the multiple reports by sex workers that show that some members of the police forces are frequent clients of clubs, where they are offered free drinks and sexual services as a way to ensure that no raids will take place (at least not without warning) (Riopedre 2010).

27 This seems to change, however, when potential victims are identified at the border. If they are identified as migrant sex workers then, they can be labelled as de facto victims of sexual exploitation (Gobierno de España 2011).
} 
Each Party shall ensure that, if the competent authorities have reasonable grounds to believe that a person has been victim of trafficking in human beings, that person shall not be removed from its territory until the identification process as victim of an offence provided for in Article 18 of this Convention has been completed by the competent authorities ...

By the logic of the Guardia Civil, in which there are reasonable grounds to assume that every sex worker is a potential victim of trafficking, no migrant sex worker in an irregular situation should be expelled from Spain before a thorough investigation regarding their situation took place. Yet this is most certainly not the case. Multiple media reports ${ }^{28}$ attest to the fact that large numbers of undocumented migrant sex workers who are detected by the Guardia are set to be deported with no care as to a potential trafficking situation, even when strong trafficking indicators (such as violence and movement control) are clearly identified.

In fact, despite the recurrent abolitionist rhetoric that considers all sex workers as (potential) victims (of trafficking), jurisprudence from the Supreme Court and the assessment of the Fiscal Ministry (Freire 2013: 43-44) determine that for exploitation to be considered in connection of trafficking for sexual exploitation, it needs to be clear and evident - which is understood to mean more than simply obtaining an agreed upon share of the sex worker's profits.

Moreover, it seems that the only people who are officially labelled as victims (and thus benefit from protection and other forms of aid) are those who decide to testify against their traffickers (Piscitelli 2006: 8). Even in such cases, however, the protection and aid are not always guaranteed and some victims have had their claims ignored, particularly if they are not able to point towards new and valuable evidence against "organised criminal networks" (Piscitelli 2011: 19; Piscitelli 2012: 286).

If foreigners are found to be in an irregular situation in Spain, they can be detained for up to seventy-two hours and receive an "expulsion letter," which notifies them that they are supposed to leave the country. Afterwards, one of two things happens: the migrants are released or, with the authorisation of a judge, they can be relocated to a Foreigners' Internment Centre (CIE) for up to sixty days. Should the migrants already possess such a letter, they will be automatically relocated to a CIE to be expelled from the country.

Although some migrant sex workers are let go after being identified during raids as being irregularly in Spain, a large number are taken directly to the CIEs. In these places, which resemble prisons, many of them are not made aware of their rights (which include the right to appeal their expulsion) and are submitted to a number of human rights violations, including sexual assault. Among these migrants set for deportation, NGOs have detected a number of trafficking victims who have not received any sort of

\footnotetext{
${ }^{28}$ See for instance the work of Analise Infante for BBC Brasil.
} 
support from the authorities (Women's Link Worldwide 2012). In some cases deportation cannot take place for a number of reasons (including insufficient funds) and migrants may end up being set free after being detained for weeks without having committed any crimes (Arella et al. 2006: 74).

Even the victims who are in fact identified do not seem to always fare better. According to Amnesty International, even when victims report their situations and agree to testify against their traffickers, it is not uncommon for expulsion orders to be brought against them, being at most halted during the judiciary proceedings (Gonzales and Olmos 2011). As per the terms of the Ley de Extrangería, as modified in 2010, only those victims who have exceptional personal circumstances or who played a significant role in the judicial proceeding against a trafficking network are accorded resident permits which extend beyond these proceedings. In some places, a victim may have to wait a whole year to obtain a residency permit, which does not include a work authorisation (de la Riva et al. 2008: 45). Furthermore, according to prominent anti-trafficking NGO Proyecto Esperanza, Spain's anti-sex work perspective, while not explicitly included in the legislation, makes itself known in practice. To obtain a residence permit, victims must not only distance themselves from their traffickers, but from sex work altogether (Amnistía Internacional 2009: 42-43). This is highly problematic considering that for some victims sex work is still the most viable and desirable source of income.

Although the government claims that every victim who has undergone an identification procedure has received adequate support, there is no official data regarding the number of victims that have been referred to the NGOs that are supposed to provide it (E-Notes 2010: 204). This "support" is also not universally well regarded. By 2010 there were only seven centres in the whole of Spain focused on sheltering trafficking victims, while fifty-five existed to support "victims of sexual exploitation in the context of prostitution" (Secretaría General de Políticas de Igualdad 2010: 4). A large number of these institutions lacked sleeping accommodations for victims; none of those that did have accommodations provided residence for male victims and only a handful could accommodate the children of trafficked women. Moreover, only a few places provided the full range of services the victims might need (Ministério de Sanidad 2012). Many of these centres are backed by religious institutions and some have such strict codes of conduct (regarding dress code, daily schedule, etc.) that they are regarded as akin to prisons by the victims. There are a number of recorded cases where people have escaped from these centres which were supposed to help them, preferring to try their own luck rather than feel incarcerated (Federación de Mujeres Progresistas 2009).

\section{Portugal}

\section{Local Legislation and Policies}

The first signs of an anti-trafficking legislation in Portugal date back to the 1980s when Decreto-Lei $(D L)$ 400/82 created a new Portuguese Penal Code. It contained, under the 
"sexual crimes" heading, article 217, which punished the person who handled, seduced or deviated someone else (even with his or her consent) to engage in prostitution or acts that went against modesty or sexual morality in another country. Monetary gain, violence and grave threat were considered aggravating circumstances to the crime.

The following decade led to a revision of the Penal Code by $D L 48 / 95$, which shifted trafficking to article 169 under the "crimes against sexual freedom" heading. It punished anyone who, through violence, grave threat, ruse or fraud, took another person to a foreign country to engage in prostitution or relevant sexual acts, ${ }^{29}$ exploiting their situation of abandonment or necessity. This already represented a considerable shift, going from punishing basically anyone involved in migratory movements that resulted in sex work, regardless of the consent of the alleged victim, to focusing solely on those who did so using underhanded means and exploiting a (debatable) situation of vulnerability. This requirement of exploitation of a situation of vulnerably in the recruitment process was dropped three years later by $D L 65 / 98$.

Article 169 was altered a third time by Lei 99/2001, which punished those who, through violence, grave threat, ruse or fraud, abuse of authority resulting from a hierarchical, economic or work dependency or by taking advantage of a situation of special vulnerability, recruited, transported, harboured or enabled someone to engage in prostitution or relevant sexual acts in a foreign country. Although the conduct and means were here very clearly delineated, like the provisions before it the new reading of the law continued to be based on the assumption that engagement in prostitution is, in itself, exploitative. This was supported by the fact that there were no separate provisions for internal trafficking, which was punishable under article 170 (lenocinio, the exploitation of the prostitution of others). Other forms of exploitation in the context of trafficking were not contemplated.

By 2004 Portugal had ratified the UN Trafficking Protocol, but it was not until 2007, through Lei 59/2007, that its definition of trafficking fulfilled the Protocol's requirements. Now typified in article 170, under the "crimes against personal freedom" heading, the law reads (in part),

Whomsoever offers, delivers, recruits, accepts, transports, houses or harbours a person for sexual exploitation, labour exploitation or organ removal:

a) Through violence, abduction or grave threat;

b) Through ruse or fraud;

c) Abuse of authority resulting from a hierarchical, economic, work or familial dependency;

d) Taking advantage of mental incapacity or a situation of special vulnerability of the victim; or

29 "Relevant sexual acts" may encompass not only direct sexual acts, but also those that do not involve direct sexual contact (such as striptease and erotic pole dance) (Peixoto et al. 2005: 72). 
e) By obtaining the consent of the person who has control over the victim; ...

Besides expanding the forms of exploitation, the terms "prostitution and other relevant sexual acts" were substituted by "sexual exploitation." No definition, however, is given to the term. Yet, as the legislation regarding lenocinio (now article 169) continues to punish whomsoever, "professionally or with the intention of profit, foments, encourages or facilitates the engagement in prostitution by another person," without considering the consent of the supposed victim, it is not unreasonable to consider that prostitution, unless completely autonomous, could be encompassed in the sexual exploitation label. In this way, it seems that Portugal's trafficking legislation, like Spain's and Brazil's, may have been strongly influenced by the country's abolitionist approach towards prostitution.

In the same year these major changes were brought to the trafficking legislation, Lei 23/2007, which regulated the situation of foreigners in Portugal, introduced specific provisions for trafficking victims. The first was the concession of a reflection period, ranging from thirty to sixty days, during which deportation procedures are halted and necessary medical and psychological aid are provided. After the reflection period, a renewable one year permit to reside in the country may be granted to victims who have cut all ties with traffickers and whose personal circumstances justify their stay. These circumstances can be related to the safety and health of the victims or their families, their family situation or other situations of vulnerability.

Two points concerning the aforementioned law are of particular interest. The first is that although Section V of the law deals with both victims of trafficking and those who have been smuggled into the country, there is not, in the case of the trafficking victims, a "usefulness requirement." Irregular migrants, on the other hand, must not only cut contact with smugglers, but must also show a willingness to cooperate with the relevant authorities and be in a situation where an extension of their stay in the country is necessary due to their role in the investigation or criminal proceedings taking place to be able to benefit from a residence permit. The second is that, as clarified by $D L$ $368 / 2007$, a "victim of trafficking" (who is able to benefit from the full provisions of the law) is any person that, according to the assessment of the proper authorities, shows any signs of having being victimised by trafficking. Thus, in theory a potential victim should also be able to benefit from these legal provisions.

Following these changes to the Portuguese legislation, three national trafficking plans have been published (República Portuguesa 2006; Presidência do Conselho de Ministros 2010, 2013), setting up goals and directions for the management and eradication of the crime in Portugal. While the first plan made a cursory reference to the potential link between prostitution and trafficking, this was not the case with the subsequent plans. Overall, rather than explicitly singling out migrant prostitution as almost synonymous to trafficking as it happened in Spain, Portugal's plans take a much broader view towards this criminal phenomenon. 


\section{Law and policies into practice}

When talking about identifying victims of trafficking in Portugal, one must consider two distinct moments: pre and post 2008. While data for "victims of trafficking for sexual exploitation" was available before 2008, it did not reflect the reality of the situation, as the category included both victims of trafficking and of lenocinio, that is to say, those who worked in prostitution and were "exploited" by a third party (Santos et al. 2007: 73).

After 2008, as a response to the significant shift in the Portuguese trafficking legislation and the elaboration of the First National Anti-Trafficking Plan which took place the year before, the process of identifying trafficking victims and gathering information about them improved significantly. In that year the Human Trafficking Observatory $(O T S H)$ was established, having as one of its main objectives producing and collecting standardised trafficking data which is made available to the public. The current monitoring system used to identify and deal with trafficking victims is divided in three phases: flag, identify and integrate (ICMPD 2010: 218).

Potential trafficking victims are flagged either by the organs of criminal police (OCP) ${ }^{30}$ - primarily during "actions against human trafficking" 31 - or by NGOs and privatepublic entities. A flagged victim is a person who demonstrates enough indicators of trafficking to warrant a closer examination of their situation. These trafficking indicators, ${ }^{32}$ which are available to OCP officers in the form of a checklist, are very similar to the ones developed by the ILO and the European Commission (E-notes 2010: 190).

If there is enough evidence to suspect a possible case of trafficking, the trained OCP officer files a GUR (Sole Registering Guide) with the relevant information about the potential victims and their situation. ${ }^{33}$ Flagging victims leads to an active investigation of their case by a specialised team during which their status as victims of trafficking can be confirmed or not. Non-confirmed cases are usually divided into two categories:

\footnotetext{
${ }^{30}$ These include police forces (the National Republican Guard, the Judiciary Police and the Public Security Police) and the Serviço de Estrangeiros e Fronteiras (SEF, the organ responsible for dealing with foreign nationals on Portuguese soil). In practice, the Judiciary Police and the $S E F$ are the only ones with investigative powers. Cases involving foreign victims are usually passed to the jurisdiction of the SEF (GRETA 2012: 41).

${ }^{31}$ There were 10,982 such inspections/raids in 2011, most of them conducted by the $S E F$ and some with the cooperation of the other OCP and even the Spanish police. Portuguese authorities recognise that these inspections are aimed not only at detecting cases of human trafficking, but also of irregular migration and illegal employment (SEF 2011).

32 These indicators include, among others, control of movement, threats, physical violence, inability to access identification documents and signs of fear/depression.

${ }^{33}$ Should the potential victim be identified by an NGO or a public organ a GS (Flagging Guide) is filled instead. It is relevant to note that few victims flagged by NGOs are formally identified and as such most benefit from no official assistance (GRETA 2012: 29).
} 
victims of other offenses ${ }^{34}$ who nonetheless do not qualify as trafficking victims and cases which have been shelved due to lack of evidence.

During the confirmation process the presumed victims are allowed to remain in the country regardless of their migration status. Adequate support (medical, psychological, legal) and shelter are provided as needed. ${ }^{35}$ In case the trafficking victim status is confirmed, a reflection period is given, lasting between thirty and sixty days. Victims are placed in temporary shelters specifically designated for trafficking cases, which are coordinated by the Shelter and Protection Centre $(C A P)$, where they continue to receive support. ${ }^{36}$ After the reflection period, the victims may decide whether they would like to contribute to the criminal proceedings which are taking place.

Afterwards, there are two main paths for the victims. If victims are unable or unwilling to remain in Portugal, support is given for their assisted return. Besides the relevant Portuguese authorities, this may involve the International Organization for Migration (IOM), public institutions from their country of origin (such as consulates) and relevant members of civil society.

If they elect to remain in Portugal, but are in an irregular situation, they may apply for a residence permit, which may be granted if their situation warrants it even if they did not cooperate with the judicial proceedings against their traffickers. If they are allowed to remain in the country, adequate support will be given to allow them to fully integrate into Portuguese society.

While the Portuguese authorities continue to affirm that the process is not associated with cooperation with the judicial system, some NGOs claim that to be identified as a victim of trafficking and benefit from the provisions granted to them, this is in practice a requirement (GRETA 2012: 29), and they are thus pressured to encourage victims to collaborate (Gomes et al. 2011: 175). Moreover, Lei 23/2007, as previously mentioned, requires victims to cut all ties with their alleged traffickers to receive a residence permit. As we have seen with Spain, this may in practice mean that trafficking victims are pressured into leaving the sex industry altogether if they want to receive any of the benefits they are legally entitled to.

\footnotetext{
${ }^{34}$ These other offenses are most often "connected" crimes which include slavery, lenocínio, domestic violence, rape, the retention of documents and aid to irregular migration.

${ }^{35}$ Neves and Pedra (2012: 117) claim, however, that over half of existing trafficking victims do not receive any assistance.

${ }^{36}$ For a number of years, however, the $C A P$ only had a six-person shelter available in Portugal, leading some victims to be placed in non-specialised centres. This shelter only served women and children, which was particularly problematic considering the high numbers of male victims of labour exploitation (GRETA 2012: 7). Moreover, having only one centre meant putting all victims together, regardless of their personal circumstance and needs (such as protective custody) (Gomes et al. 2011: 177). As of 2013, the $C A P$ was given the necessary means to open a shelter for male victims of trafficking, which now represent the majority of confirmed cases.
} 
Although data from 2010 shows that residence permits have been given to a large percentage of the trafficking victims which have asked for them (OTSH 2011: 33-34), in practice all permits provided up to that year (fifteen in 2008, two in 2009 and ten in 2010) were granted due to cooperation with the judicial authorities (GRETA 2012: 32).

While the Trafficking Observatory's identification mechanism seems to be living at least in part to its potential, there is still room for improvement (E-notes 2010: 190). ${ }^{37}$ The $O T S H$ itself notes that the $G S$ and the $G U R$ are not always properly filled, making it difficult to collect accurate data.

There are also two problems linked specifically to information provided by NGOs. First, cases submitted through the $G S$ receive a separate status from those that come from the GUR, as if they were less relevant. Secondly, it appears as if only a small percentage of NGOs dealing with trafficking acknowledge the cases they detect by filling the $G S$ and even those who do so do not always share all pertinent information. This is mainly due to the fact that many NGOs do not trust the current system to focus on the victims' best interests (Neves and Pedra 2012: 23).

Other problems are found when it comes to data collection from the police forces and migration officers. OCP officers are not always respectful while dealing with sex workers (among whom most potential victims of trafficking for sexual exploitation are flagged), who have reported cases of violence and extortion against them perpetrated by those who are in theory in charge of protecting them (Pereira 2010). Before the establishment of the OTSH mechanism it was very common for the police to turn sex workers who were in the country irregularly to the $S E F$ for immediate deportation without taking the time to assess their situation and flag potential trafficking cases, particularly in the case of Brazilian women (Santos et al. 2007: 120-121).

Although the situation seems to have improved with the new mechanism, it is still not perfect. In the words of a specialist interviewed during the evaluation of the First Portuguese Anti-Trafficking Plan: "We continue to feel that there are organs of criminal police that do not know where to find the legislation, do not know who to identify and this is very grave" (Gomes et al. 2011: 167). On top of that, it seems that not all cases that are flagged by the OCP end up in the official statistics. In some estimates, existing problems mean that the actual number of trafficking victims is at least three times greater than the number of flagged cases (Neves and Pedra 2012).

Like in Spain, many sex workers do not approve of the investigation process, which is based primarily on the inspection/raid model, as it negatively impacts business and

\footnotetext{
37 Nevertheless, the system in itself seems to be favourably viewed, as the International Centre for Migration Policy Development (ICMPD) has been working with the Portuguese Ministry of Internal Affairs in the development of a human trafficking data collection system based on the OTSH model (Vermeulen and Paterson 2010: 4).
} 
results in the deportation of many of those who are in an irregular situation (Riopedre 2010: 654). Moreover, although the Portuguese trafficking-detection mechanism is much more refined than the Spanish, it has not been immune to being misused by corrupt police and migration officers (Pereira 2010).

It is relevant to consider in this context that the investigative processes to detect potential exploitation cases are almost exclusively focused on foreign sex workers. As such, while policies and practices in Portugal are much closer to UN standards, its antitrafficking actions are, like in Spain, still used as a form of migration control (Oliveira 2012: 38).

In short, in Portugal there is an extensive, although not infallible, process of investigation that is undertaken to label someone a trafficking victim, which in turn is no longer synonymous to being a victim of lenocínio. Moreover, unlike in Spain and despite the ambiguous wording of the Portuguese legislation, migrant sex workers are not automatically seen as having been trafficked. Even if a Brazilian sex worker is being "exploited," in the terms of the Portuguese legislation, by a third party (by, for instance, sharing any percentage of her earnings), this does not make her automatically a victim of trafficking.

The real problem which seems to remain is the definition of "exploitation of a situation of special vulnerability" which will qualify a situation as trafficking even in the absence of more obvious indicators, such as threats or violence. This seems to be a particular issue when it comes to Brazilian women, who seem to be less often submitted to total deceit and violence. In the words of a Portuguese magistrate,

It is precisely the concept of "special vulnerability" which raises more questions. Is the young woman from Goiás, who has three children, is a single mother, unemployed, has extremely poor parents and has to come to Europe in these circumstances in a situation of extreme vulnerability? Jurisprudence will tell. (Santos et al. 2007: 284).

The possibility that the "poverty as force" rhetoric will be used in the building of trafficking cases against migration networks, which are subsequently re-labelled as criminal networks or "mafias," is thus left in the air.

\section{Conclusion}

The understanding of what constitutes a trafficking victim is different in all three countries and for the most part does not fulfil the minimum standards established by the UN Trafficking Protocol. While its policies adopt the UN definition, Brazil falls short of it in both its legislation and in practice, focusing almost exclusively (at least on a transnational level) on its understanding of trafficking for sexual exploitation. Spain possesses an adequate legislation which is not widely used and policies which are still 
mostly focused on a too broad understanding of sexual exploitation which encompasses all forms of prostitution. Portugal is the only one among these three countries whose legislation and policies seem to conform to a large degree to the UN definition and standards, although it still has room for improvement when it comes to putting policies into practice. ${ }^{38}$

All three countries have their unique interpretation of "victim of trafficking (for sexual exploitation)." These concepts are not only incompatible between countries, but also often internally contradictory, with the implemented policies often failing to reach the standards set by the legislation. Much seems to depend on how the term "sexual exploitation" is interpreted. Because of their abolitionist position, Brazil, Spain and Portugal consider sex work as exploitative to some extent in their criminal codes. However, none of them actually legally define "sexual exploitation" in the context of trafficking, leaving it to be spelled out by secondary policies and jurisprudence. This leads to very different scenarios.

Brazil takes a dual and contradictory position on the subject. Its consular authorities (and consequently official statistics) separate migrant sex workers and trafficking victims, as does its Ministry of Justice and related organs. In practice, however, the Federal Police and the judicial system conflate both categories, keeping in line with the legislation which equates trafficking to non-autonomous migrant sex work, particularly if it involves (poor, non-white) women who are considered to be "in a position of vulnerability."

The country also takes a double approach to the classification of victims. Abroad, the consulates rely on victims of trafficking to not only label themselves as such, but to also explicitly ask for help from the Brazilian authorities. Inside Brazil, however, the assessments made by the Federal Police and/or the judiciary system supersede the opinions of the alleged trafficking victims, with the frequent imposition of the victim label being made upon those who see themselves as migrant sex workers, both before and after they leave the country to work abroad.

In Spain, trafficking policies are strongly supported by a crimmigration approach whose main concerns are the security of the Spanish borders against irregular migration and the persecution of traffickers (Amnistía Internacional 2009: 40-41). Moreover, the declared anti-prostitution stance of the government, although not reflected in a prohibitionist legislative model, does mean that sex work - regardless of its conditions is always viewed as sexual exploitation and thus needs to be monitored and (in some measure) actively combated. Although Spain affirms the validity of the UN trafficking

\footnotetext{
${ }^{38}$ The fact that Portuguese and Spanish laws are much more UN-compatible may be due to the fact that these countries are also constrained to a similar definition of trafficking by two other instruments and organisations (the Council of Europe's 2005 Trafficking Convention and the EU's Directive 2011/36/EU), which gave added pressure (and in the EU side, the looming possibility of sanctions for non-compliance) to adopt the standard.
} 
definition, which is mirrored in its most recent legislation, the "known" victims of trafficking who are quoted by the Spanish government are often all migrant women who engage in prostitution.

The conflation of migrant sex work and trafficking in Spanish policies is justified by the alleged inherent vulnerability of all (female) migrant sex workers. In practice, this is done to legitimise raids that result in the expulsion of undocumented migrants. This becomes clear when we consider that the country becomes much more discerning regarding who can be labelled as a victim when it comes to extending benefits enshrined in law and policy.

Although the Guardia Civil seems, at first sight, to consider the self-classification of victims, the distinction that is made between those that denounce potential trafficking situations or not is ultimately meaningless. The final decision on whether or not to label a person as a trafficking victim and whether or not that person has achieved a "sufficient level of victimhood" to benefit from certain provision is made by government officials. Only those who report their traffickers and participate in proceedings against them are counted and only those whose testimony is useful are able to reap full benefits. Although club managers and apartment owners may be charged for being proxenetas, foreign sex workers are rarely acknowledged as victims of rufianismo and even more rarely receive any benefits from this victim status. They are simply treated as undocumented migrants, being jailed for a few days before receiving expulsion orders or being sent to a foreigners' detention centre.

In Portugal, the extensive investigation process into potential trafficking cases, although privileging the findings of the OCPs, shows that not all irregular migrant sex workers are classified as victims and moreover that not all cases where these sex workers are victimised are automatically classified as trafficking. Portugal very clearly separates its interpretation of sexual exploitation (lenocínio), migrant sex work and trafficking.

The self-classification of victims is very likely to play a role on whether or not a person is flagged as a potential trafficking victim. Ultimately, however, the labelling of a person as a victim (and all the potential benefits this labelling may allow for) is in the hands of designated officials of the Portuguese government. This may mean that some people who consider themselves as trafficking victims may not benefit from the full extent of governmental aid, while some who consider themselves as migrant sex workers may be labelled as victims against their will. The major problem that still remains is the interpretation given to the concept of "abuse of a position of vulnerability," which may lead to the mislabelling of certain situations as trafficking since in Portugal, like in Brazil and Spain, there is still the lingering perception that certain types of women are unable to consent to migrant sex work.

These contradictory and incompatible concepts have some severe consequences at a transnational level. The first one is that this results in incompatible cross-comparable 
statistics. Considering that Brazil and Spain - the countries which most often push the narrative of a large quantity of Brazilian victims of trafficking for sexual exploitation in the Iberian countries - both treat, in some respect, migrant sex workers as synonymous to trafficking victims, this may mean that this large flow assumption is flawed.

From a more practical standpoint, incompatible definitions may also cause direct problems for both migrant sex workers and trafficking victims. It is possible that a Brazilian migrant sex worker could be labelled (against her will) as a potential trafficking victim in Spain, while not being labelled as such in Portugal. In both countries victims of trafficking recognised by Brazilian consular authorities may not be officially recognised as victims by the national governments and thus may be deported without receiving any support. In all cases the Brazilian migrant is susceptible to being harassed by members of the brigades responsible for detecting trafficking victims during the "identification" process.

Considering the existing problems which arise due to these mismatched legislation and policies and the fact that there has been considerable time, money and political will spent in developing a network of transatlantic cooperation regarding the subject, it is somewhat surprising that little has been done to change the situation. Much of that is a reflection of the fact that existing legislation and policies, while not necessarily complying with international anti-trafficking standards and goals, have proved to be particularly efficient in other ways.

Trafficking policies have a long history of being used primarily not to stop traffickers and protect victims, but to constrain migration and discourage sex work (GRETA 2013: 22; Oliveira 2012; Piscitelli 2006: 78). By using a "protection of the human rights of victims rhetoric," the limitation and curtailment of the rights of migrants, sex workers and even certain types of women is justified.

In the case of Brazil, Spain and Portugal, this is very clear both inside their territories and at their borders. The "rescue" of trafficking victims has enabled the dissemination of large number of raids in spaces used primarily by sex workers, disrupting and discouraging business without making it illegal. These raids result in the detection of comparatively few victims, but have enabled the deportation of a large number of undocumented migrants. At the borders, the "detection" of trafficking victims has allowed for massive profiling of migrants, both before and after they leave their own country. "For their own good," certain types of (poor, non-white, female) migrants have had increasingly restricted access to legitimate migration channels.

Considering all this, the inconsistent and incompatible definitions of "victims of trafficking (for sexual exploitation)" and particularly their frequent conflation with migrant sex workers is perfectly understandable. Moreover, while the concepts can be manipulated to restrict both migration and sex work, it seems very unlikely that clearer and more precise definitions will be established. 


\section{References}

Abrantes, P. (2013). Secretário nacional de Justiça apresenta plano para enfrentamento ao tráfico de pessoas [National Justice Secretary presents plan to confront human trafficking]. http://www.estado.rs.gov.br/noticias/1/114101/Secretario-nacional-deJustica-apresenta-na-Capital-plano-para-enfrentamento-ao-trafico-de-pessoas/1/258/. Accessed 26 August 2013.

Agustín, L. M. (2007). Sex at the margins: Migration, labour markets and the rescue industry. London: Zed Books.

Amar, P. (2009). Operation Princess in Rio de Janeiro: Policing 'Sex Trafficking', Strengthening Worker Citizenship, and the Urban Geopolitics of Security in Brazil. Security Dialogue, 40(4-5), 513-541.

Amnistía Internacional (2009). Una vida sin violencia para mujeres y niñas. Las otras víctimas de violencia de género: violencia sexual y trata de personas [A life without violence for women and girls. The other victims of gender violence: sexual violence and human trafficking]. Madrid: Amnesty International.

Andreu, J. (2013). Burdeles sin salida [Brothels without exit]. http://sociedad.elpais.com/sociedad/2013/04/12/actualidad/1365787141_961396.html.

Accessed 14 April 2013.

Arella, C. I., Bessa, C. F., Lazo, G. N. \& Vartabedian, J. (2006). Una aproximación a la vulneración de los derechos humanos de las trabajadoras sexuales en la ciudad de Barcelona [An approximation of the infringement of the human rights of sex workers in the city of Barcelona]. Barcelona: Institut Català de la Dona and Regidoria de Dona $\mathrm{i}$ Drets Civils.

Blanchette, T. G. (2012). Como uma política de direitos humanos está sendo utilizada para reprimir as prostitutas [How a human rights policy is being used to repress prostitutes]. Beijo da Rua, April, 16-19.

Blanchette, T. G., \& da Silva, A. P. (2010). Mulheres vulneráveis e meninas más: Uma análise antropológica de narrativas hegemônicas sobre o tráfico das pessoas no Brasil [Vulnerable women and bad girls: an anthropological analysis of the hegemonic narratives about human trafficking in Brazil]. In A. Pacelli Ferreira, C. Vainer, H. Póvoa Neto \& M. de Oliveira Santos (Orgs.), A Experiência migrante: entre deslocamentos e reconstruções (pp. 325-360). Rio de Janeiro: Garamond.

Blanchette, T. G., \& da Silva, A. P. (2011). O mito de Maria, uma traficada exemplar: confrontando leituras mitológicas do tráfico com as experiências de migrantes brasileiros, trabalhadores do sexo [The myth of Maria, an exemplary trafficking victim: 
confronting mythological readings of trafficking with the experiences of Brazilian migrant sex workers]. Revista Interdisciplinar da Mobilidade Humana, 19(37), 79-105.

Carvalho Vallim, D. (2010). Um estudo sobre o tráfico de mulheres para exploração sexual: o encontro entre Estado e ONG's na construção de uma política pública [A study about trafficking in women for sexual exploitation: the meeting between State and NGOs in the construction of a public policy]. Master's thesis, Universidade Federal Fluminense, Niterói.

Cortes Generales (2007). Ponencia para elaborar un dictamen informativo sobre la situación actual de la prostitución en nuestro país [Paper to produce an informative legal opinion regarding the current situation of prostitution in our country]. Boletín Oficial de las Cortes Generales, 367.

de Castilho, E. W. (2006). A legislação penal brasileira sobre tráfico de pessoas e imigração ilegal/irregular frente aos Protocolos Adicionais à Convenção de Palermo [Brazilian penal legislation regarding human trafficking and illegal/irregular migration in face of the additional Protocols to the Palermo Convention]. Paper presented at the I Seminário Luso-Brasileiro Sobre Tráfico de Pessoas e Imigração Ilegal, Cascais (Portugal), November.

de La Riva, M. C., Burgos, J. G., \& Teresi, V. M. (Coords.). (2008). Memoria del Seminario Internacional Articulación de la Red Hispano-Brasileña en el Contexto de la Atención a las Brasileñas Victimas de Trata [Memorandum of the International Seminar Articulation of the Hispanic-Brazilian Network in the context of attention to Brazilian women who were victims of trafficking]. Madrid: Instituto Universitario de Desarrollo y Cooperación de la Universidad Complutense de Madrid.

E-notes (2010). Report on the implementation of anti-trafficking policies and interventions in the 27 EU Member States from a human rights perspective (2008 and 2009). Martinsicuro, Teramo: Associazione On the Road.

Federación de Mujeres Progresistas (2008). Trata de mujeres con fines de explotación sexual en España [Trafficking of women for sexual exploitation in Spain]. Madrid: Federación de Mujeres Progresistas.

Ferreira, I. T. C. M. (2009). A Construção Social do Tráfico de Pessoas [The social construction of human trafficking]. Master's thesis, Museu Nacional, Rio de Janeiro.

Freire, S. P. (2013). Informe: Estudo exploratorio da trata de persoas en Galicia [Report: Exploratory study of trafficking in persons in Galicia]. Santiago de Compostela: Xunta de Galicia. 
Global Network of Sex Work Projects (2012). Sex work is not trafficking. $n w s p$ Briefing Paper, 3.

Gobierno de España. (2011). Protocolo Marco de Protección de las Víctimas de Trata de Seres Humanos [Framework protocol of protection of the victims of human trafficking]. Madrid: Consejo General del Poder Judicial.

Gomes, C., Duarte, M., \& Henriques, M. (Coords.). (2011). Estudo de Avaliação do I Plano Nacional Contra o Trafico de Seres Humanos [Evaluation study of the I National Plan Against Human Trafficking]. Coimbra: Universidade de Coimbra.

Gonzales, E. A., \& Olmos, F. C. (2011). La actualidad del abordaje de la trata de personas para la prostitución forzada en España. El Plan Integral y sus implicaciones para trabajadoras del sexo inmigradas [The topicality of the approach towards human trafficking for forced prostitution in Spain. The Integral Plan and its implications for migrant sex workers]. Gazeta de Antropología, 27(1).

Group of Experts on Action against Trafficking in Human Beings [GRETA] (2012). Report concerning the implementation of the Council of Europe Convention on Action against Trafficking in Human Beings by Portugal. Strasbourg: Council of Europe.

Group of Experts on Action against Trafficking in Human Beings [GRETA]. (2013). Report concerning the implementation of the Council of Europe Convention on Action against Trafficking in Human Beings by Spain. Strasbourg: Council of Europe.

Guardia Civil (2002). Tráfico de Seres Humanos - Informe General de Situación Centrado en la Explotación Sexual 2002 [Human Trafficking - general situation report focused on sexual exploitation 2002]. Madrid: Departamento de Análisis Criminal de la Unidad Técnica de Policía Judicial de la Guardia Civil.

Guardia Civil (2005). Informe Criminológico - Tráfico de seres humanos 2005 [Criminological report - human trafficking 2005]. Madrid: Departamento de Análisis Criminal de la Unidad Técnica de Policía Judicial de la Guardia Civil.

International Centre for Migration Policy Development [ICMPD]. (2010). Study on the assessment of the extent of different types of Trafficking in Human Beings in EU countries. Vienna: ICMPD.

International Centre for Migration Policy Development [ICMPD] (2011). Transatlantic Journeys - An exploratory research on human trafficking from Brazil to Italy and Portugal. Vienna: ICMPD.

Ministerio de Igualdad (2008). Plan Integral de Lucha contra la Trata de Seres Humanos con Fines de Explotación Sexual [Integral Fighting Plan Against Human 
Trafficking for Sexual Exploitation]. Madrid: Imprenta Nacional del Boletín Oficial del Estado.

Ministério da Justiça (2011). Conhecendo mais sobre o Tráfico de Pessoas e como Enfrentá-lo [Learning more about human trafficking and how to face it]. Presentation given during the Processo Participativo para a Elaboração do II Plano Nacional de Enfrentamento ao Tráfico de Pessoas, Brazil, July.

Ministério da Justiça, Secretaria Nacional de Justiça \& UNODC (2013). Relatório Nacional sobre Tráfico de Pessoas: consolidação dos dados de 2005 a 2011 [National report on human trafficking: consolidation of the data from 2005 to 2011]. Brasília: Ministério da Justiça.

Ministério das Relações Exteriores, Secretaria de Políticas para as Mulheres, Secretaria Nacional de Justiça \& Departamento de Polícia Federal (2010). Guia de Retorno ao Brasil: informações úteis sobre programas e serviços de acolhimento [Guide to return to Brazil: useful information regarding reception programs and services]. Brasília: Ministério das Relações Exteriores.

Ministério de Sanidad, Servicios Sociales e Igualdad (2012). Guía de Recursos Existentes para la Atención a Víctimas de Trata con Fines de Explotación Sexual [Guide of existing resources for the care of victims of trafficking for sexual exploitation]. Madrid: Gobierno de España.

Miranda, A., Tokarski, A. C., Gimenes, L., Vasconcelos, M., Roussenq, R., \& Selvati, T. (2009). Cidadania, Direitos Humanos e Tráfico de Pessoas. Manual para Promotoras Legais Populares [Citizenship, human rights and human trafficking. Manual for female community leaders]. Brazil: International Labour Organization.

Neves, M. S., \& Pedra, C. (Coord.) (2012). A Proteção dos Direitos Humanos e as Vítimas de tráfico de Pessoas. Rotas, Métodos, Tipos de Tráfico e Setores de Atividade em Portugal [Human rights protection and trafficking victims. Routes, methods, types of trafficking and sectors of activity in Portugal]. Lisboa: Instituto de Estudos Estratégicos e Internacionais.

Observatório do Tráfico de Seres Humanos [OTSH] (2011). Relatório Anual sobre Tráfico de Seres Humanos 2010 [Annual human trafficking report 2010]. Lisboa: Ministério da Administração Interna.

Oliveira, A. (2012). Social control of immigrant sex workers transforming a group recognized as "at risk" into a group viewed as "a risk." International Journal of Migration, Health, and Social Care, 8(1), 32-41. 
Peixoto, J., Soares, A. G., Costa, P. M., Murteira, S., Pereira, S., \& Sabino, C. (2005). $O$ tráfico de migrantes em Portugal: perspectivas sociológicas, jurídicas e políticas [Migrant trafficking in Portugal: sociologic, legal and political perspectives]. Lisboa: Observatório da Imigração.

Pereira, A. C. (2010) As noites vermelhas de dois inspectores do SEF [The red nights of two Borders and Foreigners Service inspectors]. http://www.publico.pt/temas/jornal/asnoites-

vermelhas--de-dois-inspectores-do-sef-18765625. Accessed 17 June 2013.

Piscitelli, A. (2006). Antropologia, Direitos Humanos e o Debate Sobre a Indústria Transnacional do Sexo [Antropology, human rights and the debate about the transnational sex industry]. Paper presented at the $25^{a}$ Reunião Brasileira de Antropologia, Goiânia, Brazil, June.

Piscitelli, A. (2011). Procurando vítimas do tráfico de pessoas: brasileiras na indústria do sexo na Espanha [Looking for victims of human trafficking: Brazilian women in the Spanish sex industry]. Revista Interdisciplinar da Mobilidade Humana, 19(37), 11-26.

Piscitelli, A. (2012). Revisiting notions of sex trafficking and victims. Vibrant, Virtual Brazilian Anthropology, 9(1), 274-310.

Piscitelli, A., \& Sprandel, M. A. (Chairs). Fórum 03 - Tráfico de Pessoas e Novas Flexões no Debate [Forum 03 - human trafficking and new inflections in the debate]. In $35^{\circ}$ Encontro Anual da ANPOCS, Caxambú, Brazil, 2011.

Presidência do Conselho de Ministros. (2010). Resolução do Conselho de Ministros n. ${ }^{\circ}$ 94/2010, que aprova o II Plano Nacional contra o Tráfico de Seres Humanos [Council of Ministers Resolution 94/2010, approving the II Plan Against Trafficking of Human Beings]. Diário da República, 1. a série(231).

Presidência do Conselho de Ministros. (2013). Resolução do Conselho de Ministros n. ${ }^{\circ}$ 101/2013, que aprova o III Plano Nacional contra o Tráfico de Seres Humanos [Council of Ministers Resolution 101/2013, approving the III Plan Against Trafficking of Human Beings]. Diário da República, 1. a série(253).

Procuradoria da República no Estado do Rio de Janeiro (2013). Tráfico de PessoasPrevenção, Repressão, Acolhimento às Vítimas e Parcerias [Human trafficking prevention, repression, victim reception and partnerships]. Public Hearing conducted in Rio de Janeiro, May.

República Portuguesa (2006). I Plano Nacional contra o Tráfico de Seres Humanos (2007-2010) [I National Plan against the Trafficking of Human Beings (2007-2010)]. Lisboa: Governo Português. 
Riopedre, J. L. (2010). Inmigración Colombiana y Brasileña y Prostitución Femenina en la Ciudad de Lugo: Historias de Vida de Mujeres que Ejercen la Prostitución en Pisos de Contactos - Volumen II Anexos [Columbian and Brazilian migration and female prostitution in the city of Lugo: life stories of women who perform prostitution in apartments - Volume II Annexes]. Doctoral thesis, UNED, Madrid.

Santos, B. S., Gomes, C., Duarte, M., \& Baganha, M. I. (2007). Tráfico de mulheres em Portugal para fins de exploração sexual [Trafficking of women in Portugal for sexual exploitation]. Coimbra: CES and CAIM.

Secretaría de Estado de Servicos Sociales y Igualdad \& Delegación del Gobierno para la Violencia de Género (2012). IV Informe de Seguimiento del Plan Integral de Lucha contra la Trata de Seres Humanos con Fines de Explotación Sexual. Año 2012 [IV monitoring report of the Integral Fighting Plan Against Human Trafficking for Sexual Exploitation. Year 2012]. Madrid: Ministério de Sanidad, Servicos Sociales y Igualdad.

Secretaría General de Políticas de Igualdad. (2010). Informe sobre el estado de situación del Plan Integral de Lucha contra la Trata de Seres Humanos con Fines de Explotación Sexual I [Report on the state of the situation of the Integral Fighting Plan Against Human Trafficking for Sexual Exploitation I]. Madrid: Ministerio de Igualdad.

Secretaría General de Políticas de Igualdad \& Delegación del Gobierno para la Violencia de Género (2012). III Informe de Seguimiento del Plan Integral de Lucha contra la Trata de Seres Humanos con Fines de Explotación Sexual. Año 2011 [III monitoring report of the Integral Fighting Plan Against Human Trafficking for Sexual Exploitation. Year 2011]. Madrid: Ministério de Igualdad.

Secretaria Nacional de Justiça (2006). Relatório: indícios de tráfico de pessoas no universo de deportadas e não admitidas que regressam ao Brasil via o aeroporto de Guarulhos [Report: trafficking indicators in the universe of deported and non-admitted people who return to Brazil through the Guarulhos airport]. Pesquisas em Tráfico de Pessoas - parte 2. Brasília: Ministério da Justiça.

Secretaria Nacional de Justiça. (2008). Política Nacional de Enfrentamento ao Tráfico de Pessoas [National Policy on confronting trafficking in persons]. Brasília: Ministério da Justiça.

Secretaria Nacional de Justiça. (2013). II Plano nacional de enfrentamento ao tráfico de pessoas [II National Plan on confronting trafficking in persons]. Brasília: Ministério da Justiça.

Secretaria Nacional de Justiça and ILO (2007). Tráfico internacional de pessoas e tráfico de migrantes entre deportados(as) e não admitidos(as)que regressam ao Brasil 
via o aeroporto internacional de São Paulo [International human trafficking and migrant smuggling among deported and non-admited persons that have returned to Brazil through the São Paulo international airport]. Pesquisas em Tráfico de Pessoas - parte 3. Brasília: Ministério da Justiça.

Senado Federal (2012). Comissão Parlamentar de Inquérito "destinada a investigar o tráfico nacional e internacional de pessoas no Brasil, suas causas, consequências, rotas e responsáveis, no período de 2003 e 2011, compreendido na vigência da Convenção de Palermo." Relatório Final. [Parliamentary Inquiry Commission "to investigate national and international human trafficking in Brazil, its causes, consequences, routes and persons responsible, in the period between 2003 and 2011, during which the Palermo Convention is in full force." Final Report.] Brasília: Senado Federal.

Serviço de Estrangeiros e Fronteiras [SEF]. (2011). Relatório de Imigração Fronteiras e Asilo 2012 [Immigration, borders and asylum report 2012]. Barcarena, Oeiras: SEF.

Surt (Org.) (2007). Obstáculos y dificultades de la reubicación de trabajadoras sexuales en el mercado laboral: Informe de investigación. Primera parte: prostitución y exclusión [Obstacles and difficulties of the relocation of sex workers in the labour market: investigation report. First part: prostitution and exclusion]. http://centreantigona.uab.cat/docs/articulos/

Obstacles $\% 20 \mathrm{i} \% 20 \mathrm{dificultats} \% 20 \mathrm{de} \% 20 \mathrm{la} \% 20$ reubicaci\%C3\%B3\%20de\%20treballado res\%20sexuals\%20al\%20mercat\%20laboral. Accessed 12 October 2012.

Teresi, V. M. (2007). A cooperação internacional para o enfrentamento a tráfico de mulheres brasileiras para fins de exploração sexual - o caso Brasil-Espanha [International cooperation to confront the trafficking of Brazilian women for sexual exploitation - the Brazil-Spain case]. Master's thesis, Universidade Católica de Santos, Santos.

Teresi, V. M. \& Healy, C. (2012). Guia de referência para a rede de enfrentamento ao tráfico de pessoas no Brasil [Reference guide to the network facing human trafficking in Brazil]. Brasília: Ministério da Justiça and Secretaria Nacional de Justiça.

Vermeulen, G., and Paterson, N. (2010). The Measurement Of Human Trafficking, Sexually Exploited \& Missing Children In The European Union. The MONTRASEC Model - The Great Leap Forward? In L. Pauwels \& G. Vermeulen (Ed.), Actualia strafrecht en criminologie 2010. Update in de criminologie V. Antwerpen-Appeldoorn: Maklu.

Women's Link Worldwide. (2012). Mujeres en los centros de internamiento de extranjeros (CIE): realidades entre rejas [Women in Foreigners' Internment Centres (CIE): reality between bars]. http://www.womenslinkworldwide.org/wlw/new.php. Accessed 2 March 2013. 